\title{
Exploring the Relationship between Foreign Investments and Carbon Emission: A Bound Test Analysis for Pakistan
}

\author{
Hina Samreen \\ Department of Mathematics and Statistics \\ Institute of Business Management \\ Karachi, Pakistan \\ hina.samreen@iobm.edu.pk \\ Zafar Mehdi \\ Department of Management \& HR \\ Institute of Business Management \\ Karachi, Pakistan \\ zafar.mehdi@iobm.edu.pk
}

\author{
Shahida Wizarat \\ Department of Economics \\ Institute of Business Management \\ Karachi, Pakistan \\ shahida.wizarat@iobm.edu.pk
}

Rizwan Ahmed

Department of Mathematics and Statistics Institute of Business Management

Karachi, Pakistan

rizwan.ahmed@iobm.edu.pk

\begin{abstract}
In this study, the theoretical and empirical effects of foreign investment, openness to trade, urbanization, and economic development on carbon dioxide emission levels $\left(\mathrm{CO}_{2}\right)$ in Pakistan were examined. Annual time series for 38 years 19702018 were utilized. The Auto Regressive Distributed Lag (ARDL) bound test has been used to estimate the model which indicates the presence of cointegration among the variables. Long-run and short-run relationships were observed between Foreign Direct Investment (FDI) and $\mathrm{CO}_{2}$ emission levels revealing that increase in FDI results in increased $\mathrm{CO}_{2}$ emission levels contributing to environmental degradation. This endorses the theory of Pollution Haven Hypothesis (PHH) in the case of Pakistan. To achieve the goal of sustainable economic development, it is imperative to consider the possible negative effects of foreign investment on the environment. The study suggests limiting $\mathrm{CO}_{2}$ emissions by adopting more advanced low carbon technologies to ensure growth and a sustainable environment. Strict implementation of environmental laws for foreign and domestic firms both by defining $\mathrm{CO}_{2}$ emission limits, installation of proper waste management plants, and imposing a pollution tax are crucial steps for the improvement of environmental quality.
\end{abstract}

Keywords-FDI; Pakistan; CO2; emissions; environment; bound test; $\mathbf{P H H}$

\section{INTRODUCTION}

Environmental pollution, climatic change, and globalwarming are some of the most concerned topics in scientific research. The last century witnessed a significant change in climate as revealed by different indicators. It is reported that there is a $0.41^{\circ}$ increase in average recorded global temperature from 1998 to 2007 as compared to the 1961 to 1990 period [1]. This weather change is a big ecological issue that has caught the attention of researchers, policy makers, international institutions, and environmentalists. According to the
Intergovernmental Panel for Climate Change (IPCC), increased human activity due to the economic liberalization and industrialization has warmed the earth by $1^{\circ}$ centigrade since the pre-industrialization era. Furthermore, the IPCC 2018 reported that the effects of global warming have been felt in many parts of the world. Nonetheless, they are not spread consistently over the globe, with different areas experiencing the impacts unexpectedly and unevenly. Among various effects, it is resulting in heavy rainfall in certain areas, especially in the high latitudes of the Northern Hemisphere, raising the risk of flooding. Further increase in global warming may aggravate the situation due to the rapid melting of glaciers, the liquefication of ice masses, and, consequently, the rising of the sea level [2].

Carbon dioxide $\left(\mathrm{CO}_{2}\right)$ emerges as a main contributor to global warming [3]. $\mathrm{CO}_{2}$ diffuses into the environment through the extraction, refining, and consumption of petroleum products and fossil fuels. There are several factors which have contributed to the rise in temperature over the last century and energy demand is one of them. A rapidly growing economy has huge energy requirements for power generation, transportation, and industrial production. Because of the onset of globalization in the early 1990s, free capital inflows along with the increase in international trade intensified the movement of foreign investment in less developed countries in various sectors [4]. There is substantial evidence that Foreign Direct Investment (FDI) enhances the productivity of host countries and promotes economic growth. Foreign investment brings capital, technology, and skill development and provides access to new markets and greater opportunities to exports [5]. The industrial sector is a key sector of an economy, vastly contributing to economic growth. Foreign resource mobilization is crucial for industrial production and growth [6]. 
The existing literature on FDI and $\mathrm{CO}_{2}$ emissions adopts two different approaches. The Pollution Haven theory, which is the major focus of attention in this study, has a hypothesis referred to as "Pollution Haven Hypothesis" (PHH) stating that foreign investment moves towards countries with poor environmental laws and conditions and less environmental taxes. The hypothesis explains that Multi-National Corporations (MNCs) relocate the industries which are more pollution intensive in nature to Less Developed Countries (LDCs) with flexible environmental regulations to avoid high environmental costs in terms of environmental taxes. This results in increasing pollution level in the host country thus becoming a pollution haven [7]. The environmental quality is critical for human health. Poor environmental conditions pose a serious risk to human wellbeing in various ways [8]. According to the World Health Organization (WHO) Global Health Observatory, poor environmental quality causes roughly 200 deaths per 100,000 people in Pakistan. Indoor air pollution induced by residential biomass fuel combustion causes about 30 deaths per 100,000 people, whereas outdoor pollution causes around 25 deaths per 100,000 people. Rapid increase in population growth, number of vehicles, unplanned and rapid urbanization, and industrialization cause air pollution, particularly Particulate Matter (PM) pollution. Traffic congestion, open air combustion of untreated solid waste, and improper management of construction and demolition waste are the main sources of air pollution in urban areas [9].

Considering the importance of foreign investment in development, growth, and prosperity, the objective of the current study is to explore if the FDI is a possible major cause of environmental degradation, and if so, ways to design a policy framework that is sustainable for economic development with minimum hazards for the environment. Numerous empirical researches often aimed to study the direct relationship of economic growth and carbon emission [10-12] and FDI and Greenhouse Gas (GHG) emissions [13, 14], while in the current study, we analyze the indirect impact of foreign investment to GHG emissions through its direct relationship with economic growth, urbanization, and trade openness. The goal of this study is to look at the evidence of this indirect relationship and see if there is a significant effect, and if so, to quantify it. This paper contributes to earlier research on foreign investment inflow and its possible harmful effects on carbon emissions to help policy makers to design policies that combat carbon emissions but not at the cost of economic growth.

\section{POLLUTION HAVEN HYPOTHESIS}

Environmental pollution is the result of human activities which the environment cannot deal with naturally. FDI is considered as a main contributor to this environmental destruction as it accelerates economic activity that results in economic growth on one hand but it also causes an increase in GHG emissions, deforestation, and biodiversity loss on the other. Authors in [15] used a non-linear estimation method to check if there is any association between environmental devastation and foreign investment in the case of the Malaysian economy for the 1965-2010 period. The results confirm that FDI results in great environmental degradation. PHH asserts that a host country with weak environmental regulation attracts more foreign investments, as profit-oriented companies try to evade costly regulatory compliance in their home countries by relocating their dirty industries in developing countries [16]. The nexus between weak environmental laws and capital inflows of polluting industries is explored in [17]. The authors considered cross-sectional data for 7 developing economies and 15 developed countries for the period from 1985 to 1990 and found that poor environmental laws in the host country encourage FDI inflow in the industries that pollute environment, while for the less polluting sector, the results were insignificant. Authors in [18] tried to explore whether private sector involvement is beneficial to the environmental quality. The study considers $\mathrm{CO}_{2}$ emission as a measure of environmental pollution, along with other variables like financial market scope, industrial sector composition, and foreign investment. The study found that greater involvement of the private sector in a developing economy resulted in environmental quality improvement. Earlier, authors in [19] analyzed the case of ASEAN economies to study the impact of capital inflow on the environmental degradation. The study used the ARDL model and time series data for 31 years (19702001). Thailand, Malaysia, and the Philippines are the countries where a significant relationship between FDI and pollution is observed. It has been observed that foreign capital inflows do not contribute to increasing pollution levels in Indonesia, while for Singapore no significant results were found. Authors in [20] studied the long run relationship between capital inflows, pollution level, and output for Malaysia using the Granger Causality test. The research employed annual per capita GDP as a proxy for income and annual $\mathrm{CO}_{2}$ emission per capita as a proxy for pollution. The study found that FDI Granger-causes GDP growth and pollution level in the short run, while in the long run, causal relationship was observed for output and FDI inflows. Authors in [21] studied the association between foreign investment and environmental policy considering 33 countries. The study found that foreign investment can influence environmental policy only if there is a sincere effort from local government to design and implement environmental rules. The study concludes that the flexibility of environmental policy depends on the degree of corruption of government officials. The authors recommended the adoption of a political economic model with imperfect product market competition along with the application of pollution tax to combat pollution. Authors in [22] used data from 112 countries to study the relationship between foreign inflows and the level of pollution. Granger causality test was employed to test the results. The authors report that for lower income groups, $\mathrm{CO}_{2}$-levels Granger-cause foreign investment inflows. Also, for middle income groups, FDI Granger-causes $\mathrm{CO}_{2}$ emissions, whereas for higher income groups there is no evidence of Granger causality.

To confirm the PHH for ASEAN countries, authors in [23] used the ARDL method on time series data for the 1970-2008 period. In the case of the Philippines, the results indicated that all the regression coefficients except for per capita gross national income are significant. Mixed results were reported in the cases of Thailand and Indonesian economies. Authors in [24] found that economies with liberalized trade policies contribute more to pollution intensity than those following 
more restrictive policies. Authors in [25] tried to explore whether free trade agreements are affecting the environment of the countries that are bound by these agreements. The Gravity model framework was used to analyze the impact of free trade agreements on bilateral $\mathrm{CO}_{2}$ emissions. The study found that weak environmental standards prevailing in low income countries result in greater pollution effect of free trade agreements, whereas, high income countries shift dirty industries to the countries where there is weak or no implementation of environmental policy, hence confirming the Pollution Haven theory. The export volume of China is a sign of greater economic activity, but also generates an enormous amount of $\mathrm{CO}_{2}$ [26]. The author calculates the size of $\mathrm{CO}_{2}$ emission by 18 exporting industries of China from 2001 to 2010 using the I-O framework. The study concludes that the increase in the volume of exports is a major contributor to the increment of the $\mathrm{CO}_{2}$ level of a country. The study did not confirm China as a Pollution Haven for developed countries. Authors in [27] empirically explored the link between energy consumed by the transport sector, $\mathrm{CO}_{2}$ emission, economic development, foreign investment, and urbanization. ARDL and VECM were used for estimation over the period from 1990 to 2015. The study found transport sector energy consumption as a significantly strong determinant of $\mathrm{CO}_{2}$ emissions in Pakistan. The study also confirms the contribution of foreign investment in $\mathrm{CO}_{2}$ emission, whereas economic growth and urbanization were found to be insignificant determinants of $\mathrm{CO}_{2}$ emission. The study recommends that the government should play a more active role in improving environmental quality by providing energy efficient solutions in the transport sector with less adverse effects on economic growth. The author in [28] selected per capita GDP in real terms, energy consumption, urbanization, transport sector intensive-energy along with fuel prices as key determinants of pollution level in Tunisia during the period from 1980 to 2014. The author claimed that the reliance of the road transport system mainly on fossil fuel usage is a major cause of $\mathrm{CO}_{2}$ emissions. The study supported the EKC theory by confirming the presence of an inverse U-shaped curve indicating the relationship between economic development and $\mathrm{CO}_{2}$ level from the transport sector.

\section{DATA SOURCES AND MODEL SPECIFICATION}

Data on economic and other key indicators were collected from World Development Indicators (WDI) over the time span from 1970 to 2018 [29]. As a determinant of environmental quality, we have used $\mathrm{CO}_{2}$ emission per capita (CO2PCAP), in metric tons. We have also considered other economic indicators due to the limited availability of carbon emission data. Gross Domestic Product Per Capita (GDPCAP) was used to define the level of economic development (in constant 2010 US \$). FDI is the net inflow of investments as a percentage of GDP (FDIPGDP). The urbanization variable (Urban) is calculated as a percentage of urban to total population. Trade to GDP ratio is a proxy for a liberal economy (TOPENESS) and was also taken from the WDI. To explore how capital inflows affect $\mathrm{CO}_{2}$ emission levels in Pakistan, the following model has been specified using EViews.

$$
\begin{gathered}
\log (\mathrm{CO} 2 \mathrm{PCAP})= \\
\beta_{0}+\beta_{1}\left(\log (\text { GDPCAP })+\beta_{2}(\log (\mathrm{TOP} \text { ENNESS })+\right. \\
\beta_{3}\left(\log (\text { FDIPGDP })+\beta_{4}(\log (\text { Urban })+\phi \quad(1)\right.
\end{gathered}
$$

ARDL-bound test estimation method, proposed in [30, 31] has been used to explore the relationship between $\mathrm{CO}_{2}$ emissions with foreign investment, GDP per capita, urbanization, and trade openness. ARDL estimation generates results in two steps. The first is the ECM results and the second is the Bounds test results. When co-integration exists, it is recommended to also report the ECM results, in case of no cointegration, we conclude with the ARDL model.

\section{DATA ANALYSIS AND DIAGNOSTIC TEST}

Tables I and II report the descriptive statistics and the correlation matrix for the variables considered in the current study. To confirm the robustness of the results, different diagnostic tests are employed which are discussed in the following section. To examine the stationarity of variables, both Augmented Dickey-Fuller (ADF) test and Phillips \& Peron (PP test) were applied. Table III shows the findings. It is revealed from unit roots tests that initially, level following variables are non-stationary like per capita $\mathrm{CO}_{2}$ emission, foreign investment, and per capita GDP, but become stationary after taking the first difference, whereas the remaining variables are stationary.

TABLE I. DESCRIPTIVE MEASURES

\begin{tabular}{|c|c|c|c|c|}
\hline Variable & Mean & Std. Dev. & Min & Max \\
\hline FDIPGDP & 0.7606914 & 0.7968646 & -0.063242 & 3.668323 \\
\hline Urban & 31.16394 & 3.422316 & 24.81700 & 36.44200 \\
\hline GDPCAP & 2.191195 & 2.162259 & -2.218736 & 8.385496 \\
\hline TOPENESS & 32.55893 & 4.043413 & 19.93229 & 38.90950 \\
\hline CO2PCAP & 0.6512522 & 0.2209307 & 0.3083813 & 0.9878324 \\
\hline
\end{tabular}

TABLE II. CORRELATION MATRIX

\begin{tabular}{|c|c|c|c|c|c|}
\hline & FDIPGDP & Urban & GDPCAP & CO2PCAP & TOPENESS \\
\hline FDIPGDP & 1.0000 & & & & \\
\hline Urban & 0.5683 & 1.0000 & & & \\
\hline GDPCAP & 0.0003 & -0.0657 & 1.0000 & & \\
\hline CO2PCAP & 0.6382 & 0.9795 & -0.0628 & 1.0000 & \\
\hline TOPENESS & 0.2612 & 0.1392 & -0.0446 & 0.0783 & 1.0000 \\
\hline
\end{tabular}

TABLE III. AUGMENTED DICKEY FULLER UNIT ROOT TEST

\begin{tabular}{|c|c|c|c|c|c|}
\hline Variable & $\begin{array}{c}\text { ADF at } \\
\text { level P- } \\
\text { value }\end{array}$ & $\begin{array}{c}\text { ADF at first } \\
\text { difference } \\
\text { (P-value) }\end{array}$ & $\begin{array}{c}\text { Order of } \\
\text { integration }\end{array}$ & $\begin{array}{c}\text { PP test } \\
\text { at level }\end{array}$ & $\begin{array}{c}\text { PP test at } \\
\text { first } \\
\text { difference }\end{array}$ \\
\hline LnCO2PCAP & 0.8561 & 0.000 & $\mathrm{I}(1)$ & 0.9221 & 0.0000 \\
\hline Ln FDI & 0.0816 & 0.0000 & $\mathrm{I}(1)$ & 0.1138 & 0.000 \\
\hline Ln Urban & 0.0144 & & $\mathrm{I}(0)$ & 0.0000 & \\
\hline LnGDPCAP & 0.8550 & 0.0000 & $\mathrm{I}(1)$ & 0.9435 & 0.0000 \\
\hline LnTOPENSS & 0.0112 & & $\mathrm{I}(0)$ & 0.0097 & \\
\hline
\end{tabular}

An optimal lag length selection is the first step in ARDL estimation. Table IV reports various lag selection criteria available in the literature. Except Schwartz Information Criterion (SIC) all three-information criteria suggest that we should consider a maximum lag length of two in this study. The * sign in Table IV defines the selected lag order by the chosen criterion. In the second step we proceed with the estimation of the ARDL model, which requires the computation and analysis of F-statistics using ARDL bound test methodology. 
TABLE IV. LAG LENGTH SELECTION

\begin{tabular}{|c|c|c|c|c|c|c|}
\hline Lag & LogL & LR & FPE & AIC & SIC & HQ \\
\hline 0 & 87.99601 & NA & 0.001465 & -3.688711 & -3.487971 & -3.613878 \\
\hline 1 & 100.7045 & 22.02806 & 0.000871 & -4.209089 & -3.968201 & -4.119288 \\
\hline 2 & 103.1279 & $4.092887 *$ & $0.000819^{*}$ & $-4.272352^{*}$ & $-3.991316^{*}$ & $-4.167585^{*}$ \\
\hline 3 & 103.9750 & 1.393006 & 0.000825 & -4.265557 & -3.944372 & -4.145822 \\
\hline 4 & 103.9809 & 0.009329 & 0.000864 & -4.221371 & -3.860039 & -4.086670 \\
\hline
\end{tabular}

Table $\mathrm{V}$ reports the calculated F-statistic and its critical values. The F-statistic (17.773) is found to be greater than the upper bound critical value (5.06) at $1 \%$ significance level which helps us reject the null hypothesis of no long-run association at $1 \%$ level of significance. Long run elasticities for both the dependent variable (carbon emissions) and the independent variables (Foreign Investment, Per capita GDP, Urbanization and Trade openness) are summarized in Table VI. The coefficients for FDI, Urbanization and trade liberalization are found to be significant at the $1 \%$ level of significance in the long run, while the coefficient on per capita GDP is found to be significant at the $10 \%$ level of significance. As expected, the estimated coefficients of all the explanatory variables carry the expected positive sign. Foreign investment opens the door to infrastructure and technological and human development in the host country [32]. A significant and positive coefficient on FDFI describes investment opportunities available at the cost of environmental degradation. A $1 \%$ increase in foreign investments causes a $0.0418 \%$ increase in $\mathrm{CO}_{2}$ emissions. The coefficient on urbanization is also found to be a positive and significant determinant of carbon emissions. High urbanization means that more people are settled in urban areas resulting in increase in human and economic activities. This result is in line with the findings in [33].

TABLE V. ARDL BOUND TEST

\begin{tabular}{|c|c|c|}
\hline \multicolumn{3}{|c|}{ F-Statistic 17.773*** } \\
\hline \multicolumn{3}{|c|}{ Critical values bound } \\
\hline Significance & Lower bound & Upper bound \\
\hline $1 \%$ & 3.74 & 5.06 \\
\hline $5 \%$ & 2.86 & 4.01 \\
\hline $10 \%$ & 2.45 & 3.52 \\
\hline
\end{tabular}

TABLE VI. LONG RUN ESTIMATES

\begin{tabular}{|c|c|c|c|c|}
\hline Variable & Coefficient & Std. error & t-statistic & Prob. \\
\hline LOG(FDIPGDP) & 0.041811 & 0.007119 & 5.873148 & 0.0000 \\
\hline LOG(GDPCAP) & 0.232906 & 0.133448 & 1.745300 & 0.0895 \\
\hline LOG(URBAN) & 1.951081 & 0.329676 & 5.918186 & 0.0000 \\
\hline LOG(TOPENESS) & 0.186990 & 0.041948 & 4.457692 & 0.0001 \\
\hline LOG(CO2PCAP) & -9.122096 & 0.480991 & -18.965208 & 0.0000 \\
\hline
\end{tabular}

A continuous growth in urbanization is responsible for the increase in the pollution level of a country causing damage to the environment, not only in industrialized nations, but also in developing economies [34]. People migrate to cities to find better health, education, and employment opportunities. This growth in urban population creates numerous challenges for urban areas due to the increase in demand and the limited resources. This unplanned population growth brings new challenges in various ways. Better infrastructure and transport facilities form a need for growing urban population. To provide transport facilities to a large urban population results in increase in the number of vehicles, resulting in more vehicular emissions. Rapid growth in urban population also exerts pressure on the availability of clean water and proper wastage and sewerage system [33]. As expected, we observed a positive and significant coefficient (0.2329) for per capita GDP growth and $\mathrm{CO}_{2}$ emissions in the long run, namely $1 \%$ increase in per capita GDP growth contributes to $0.2329 \%$ increase in $\mathrm{CO}_{2}$ emissions. This phenomenon may reflect in more economic activities and the number of vehicular emissions [35]. The coefficient (0.1869) of trade openness is also found to be positive and significant determinant of $\mathrm{CO}_{2}$ emission levels. This is a significant result explaining why Pakistan experiences a comparative advantage in the production of goods that are harmful for the environment. This result helps to conclude that in the absence of strict environmental protection laws, greater trade openness does not lead to the path of sustainable growth in the long run. Since we found evidence for a long run relationship we further tested for short run relationship by adopting the ECM-ARDL approach. The results are given in Table VII. The adjustment coefficient $(-1.0307)$ has the expected negative sign and is statistically significant. Table VII also provides the short run estimates of regressors and $\mathrm{CO}_{2}$ emissions.

TABLE VII. SHORTRUN ESTIMATES

\begin{tabular}{|c|c|c|c|c|}
\hline Variable & Coefficient & Std. error & t-statistic & Prob. \\
\hline $\begin{array}{c}\text { DLOG(CO2PCAP } \\
(-1))\end{array}$ & 0.060852 & 0.148354 & 0.410180 & 0.6842 \\
\hline $\begin{array}{c}\text { DLOG(CO2PCAP } \\
(-2))\end{array}$ & 0.040098 & 0.106818 & 0.375383 & 0.7097 \\
\hline $\begin{array}{c}\text { DLOG(FDIPGDP } \\
(-1))\end{array}$ & 0.017003 & 0.009797 & 1.735437 & 0.0917 \\
\hline $\begin{array}{c}\text { DLOG(FDIPGDP } \\
(-2))\end{array}$ & -0.000999 & 0.007147 & -0.139768 & 0.8897 \\
\hline $\begin{array}{c}\text { DLOG(GDPCAP } \\
(-1))\end{array}$ & 0.425215 & 0.261891 & 1.623635 & 0.1137 \\
\hline $\begin{array}{c}\text { DLOG (GDPCAP } \\
(-2))\end{array}$ & 0.315363 & 0.308304 & 1.022896 & 0.3136 \\
\hline $\begin{array}{c}\text { DLOG(URBAN } \\
(-1))\end{array}$ & -5.003957 & 9.281719 & -0.539120 & 0.5933 \\
\hline $\begin{array}{c}\text { DLOG(URBAN } \\
(-2))\end{array}$ & 5.684971 & 8.876761 & 0.640433 & 0.5262 \\
\hline $\begin{array}{c}\text { DLOG(TOPENES } \\
\text { S(-1)) }\end{array}$ & 0.123089 & 0.050503 & 2.437276 & 0.0202 \\
\hline $\begin{array}{c}\text { DLOG(TOPENES } \\
\text { S(-2) })\end{array}$ & 0.017732 & 0.037870 & 0.468230 & 0.6426 \\
\hline ECM(-1) & -1.030749 & 0.277675 & -3.712069 & 0.0007 \\
\hline R-square & 0.560200 & & & \\
\hline
\end{tabular}

The optimal lag length is found to be 2 for every variable thus all the short run estimates given in the Table show 2 lags for every variable. All explanatory variables are found to be insignificant, except for the coefficient on trade openness, which means trade openness contributes significantly to carbon 
emission only in the short run. The Error Correction (ECM) term is found to be significant with the expected negative sign $(-1.0307)$ which explains that whenever per capita carbon emission is above or below the equilibrium level, it automatically adjusts by $103 \%$ and the speed of adjustment occurs within the first year. The value of $\mathrm{R}$ square shows that the fitted model is a good fit and explains that the $56 \%$ variability in the model is due to the included explanatory variables. The high $p$-values of urbanization and trade openness coefficients are evident that no short run causal relationship exists between the explanatory variables and the dependent variable. Whereas a significant value of FDI at $1 \%$ and per capita GDP at $10 \%$ indicates that there is an evidence of short run causal relation from explanatory variables to the dependent variable. The highly significant ECM term (p-value 0.0007) in Table VII is evident of the causality among variables. Generally, the co-integration analysis is used to observe the possible causal relationship between the variables, at least unidirectional. But it does not provide the direction of causality. Thus, to examine the direction of causality among the variables the next step is to run a Granger causality test. Table IX provides the results. Two-way causality is observed between carbon emission and FDI. A very interesting finding of the Granger causality test is the uni-directional causality from FDI to $\mathrm{CO}_{2}$ emission per capita GDP growth, urbanization, and trade openness. This validates the hypothesis of the study that foreign investment stimulates the economic activity reflected in terms of urbanization and per capita GDP growth but also explains the environmental degradation in terms of hazardous emissions.

TABLE VIII. WALD TEST

\begin{tabular}{|c|c|}
\hline Variables & Probabilities \\
\hline FDI & 0.000 \\
\hline GDPCAP & 0.0992 \\
\hline URBAN & 0.5730 \\
\hline TOPENESS & 0.1144 \\
\hline
\end{tabular}

TABLE IX. VECM GRANGER CAUSILTY TEST

\begin{tabular}{|c|c|}
\hline Hypothesis & Probability \\
\hline LOG(FDIPGDP) does not Granger-cause LOG(CO2PCAP) & 0.0058 \\
\hline LOG(CO2PCAP) does not Granger-cause LOG(FDIPGDP) & 0.0981 \\
\hline LOG(GDPCAP) does not Granger-cause LOG(CO2PCAP) & 0.0002 \\
\hline LOG(CO2PCAP) does not Granger-cause LOG(GDPCAP) & 0.1487 \\
\hline LOG(URBAN) does not Granger-cause LOG(CO2PCAP) & 1.E-05 \\
\hline LOG(CO2PCAP) does not Granger-cause LOG(URBAN) & 0.0433 \\
\hline LOG(TOPENESS) does not Granger-cause LOG(CO2PCAP) & 0.0273 \\
\hline LOG(CO2PCAP) does not Granger-cause LOG(TOPENESS) & 0.4636 \\
\hline LOG(GDPCAP) does not Granger-cause LOG(FDIPGDP) & 0.2950 \\
\hline LOG(FDIPGDP) does not Granger-cause LOG(GDPCAP) & 0.0055 \\
\hline LOG(URBAN) does not Granger-cause LOG(FDIPGDP) & 0.4332 \\
\hline LOG(FDIPGDP) does not Granger-cause LOG(URBAN) & 0.0296 \\
\hline LOG(TOPENESS) does not Granger-cause LOG(FDIPGDP) & 0.7558 \\
\hline LOG(FDIPGDP) does not Granger-cause LOG(TOPENESS) & 0.0003 \\
\hline LOG(URBAN) does not Granger-cause LOG(GDPCAP) & 0.0820 \\
\hline LOG(GDPCAP) does not Granger-cause LOG(URBAN) & 0.1818 \\
\hline LOG(TOPENESS) does not Granger-cause LOG(GDPCAP) & 0.4591 \\
\hline LOG(GDPCAP) does not Granger-cause LOG(TOPENESS) & 0.5039 \\
\hline LOG(TOPENESS) does not Granger-cause LOG(URBAN) & 0.0045 \\
\hline LOG(URBAN) does not Granger-cause LOG(TOPENESS) & 0.7983 \\
\hline
\end{tabular}

In Table IX we also observe that per capita GDP growth causes carbon emissions in the long run. This result also suggests that a stimulated economic activity may harm the environment if certain protective measures are not adopted. No long run causality was observed in the reverse direction which means that $\mathrm{CO}_{2}$ emission does not Granger-cause economic growth, therefore a unidirectional causality is observed. This result is in contrast to the findings of [1], who asserted that any measure to control $\mathrm{CO}_{2}$ emissions may have different implications for developed and developing countries. Measures to limit or control $\mathrm{CO}_{2}$ emissions are more harmful for developing countries as compared to developed countries. To test the stability of the model, the Cumulative Sum of Recursive Residuals (CUSUSM) test was applied and the result is explained with the help of Figures 1 and 2. The plots of CUSUM test explain the stability of the ECM model. The straight lines in both Figures describe the critical values at 5\% level of significance. The CUSUM and CUSUMSQ plots lie within the drawn critical values confirming the model is stable.

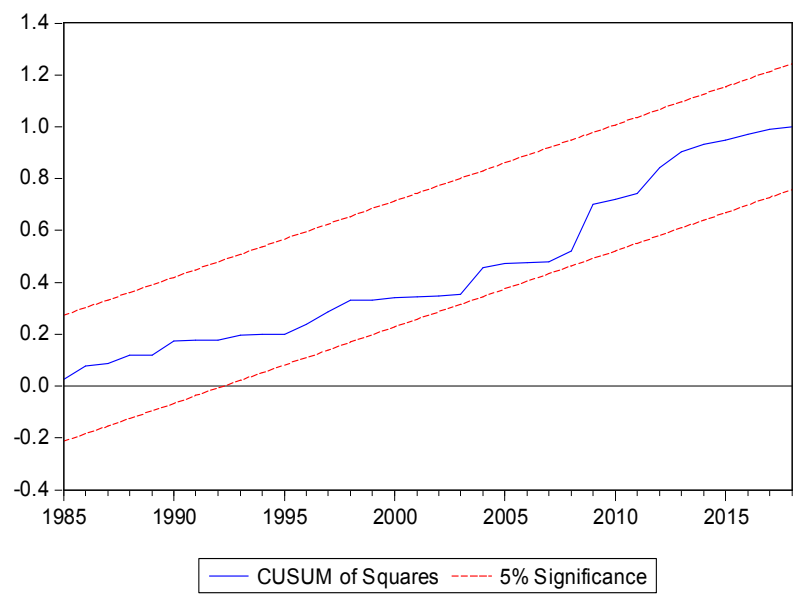

Fig. 1. CUSUM plot.

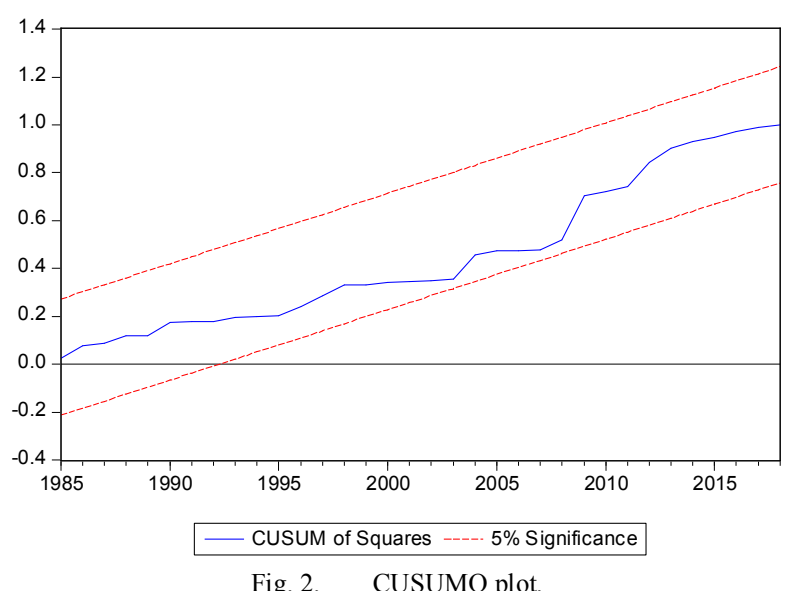

Further diagnostic tests are applied to the ECM model and the results are presented in Table $\mathrm{X}$. The results suggest that the ARDL model fits well and passes the Breusch-Pagan-Godfrey heteroscedasticity test and Breusch-Godfrey LM Test for serial correlation. 
TABLE $X . \quad$ DIAGNOSTIC TEST RESULTS

\begin{tabular}{|l|c|c|}
\hline \multicolumn{2}{|c|}{ Breusch-Pagan-Godfrey for heteroscedasticity } \\
\hline F-value & 1.034710 & Prob. F $(14,30)$ \\
\hline \multicolumn{2}{|c|}{ Breusch-Godfrey LM test of serial correlation } \\
\hline F-value & 1.178700 & Prob. F $(2,28)$ \\
\hline
\end{tabular}

\section{CONCLUSION}

In the neoliberal economic model, foreign investment is a major contributor to development through the introduction of new knowledge and technology and the creation of opportunities for employment and income growth. Therefore, the governments in host countries give lucrative offers to attract foreign investors. Our results confirm that increasing FDI causes an increase to $\mathrm{CO}_{2}$ emissions, thus contributing to environmental degradation. A positive association between $\mathrm{CO}_{2}$ emissions and FDI corroborates the PHH for Pakistan. The study suggests that before signing an agreement with the investor, host governments need to consider the possible adverse effects of FDI on the environment. Host governments should ensure that the investor company/country would adopt a clean energy technology that would reduce the pollution level. Thus, there is a need to set standards for industrial pollutants and emissions. To achieve the object of sustainable economic growth and development, governments should focus on strict implementation of policies that are more environmentally friendly and limit emissions to an ideal level. A sustainable approach is one that is low carbon in nature, such as wind and solar energy and aimed at reducing emissions but not at the cost of economic growth.

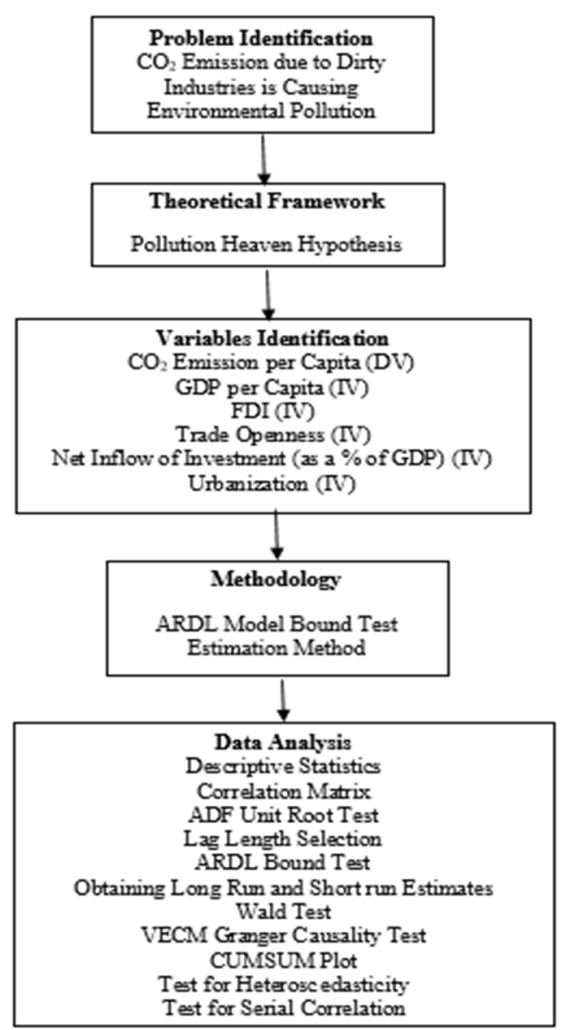

Fig. 3. Flow chart of the research.
This study establishes the understanding that a stimulated economic activity coupled with rapid urbanization results in more dependence on fossil fuel consumption and ultimately results in harmful emissions. Environmental degradation not only disturbs human life, but also puts pressure on economic activities in the long term. Urbanized activities are more energy intensive in nature. Dependence on fossil fuel consumption to cater for demands of the urban sector (electricity generation, heating, and transport) results in increased levels of pollution. With the growing population, it is difficult to limit the energy demand, hence awareness programs for the public are needed to be designed. To reduce the negative effects of urbanization, governments should monitor the technology transfer process and set standards to ensure environmental quality.

Introduction of more ecofriendly and energy efficient automobiles and provision of better public transport in the urban sector are some steps governments should adopt. There is a need to explore long term investment options that are cleaner in nature and provide sustainable solutions both for economic development and the environment. Moreover, to attract foreign investors with more ecofriendly transfer of technology, strict environmental policy, improved infrastructure, and human capital development are crucial. Figure 3 exhibits the flow chart of the research conducted to determine if there is a relationship between carbon emissions and FDI.

\section{APPENDIX}

\begin{tabular}{ll} 
& \multicolumn{1}{c}{ LIST OF ACRONYMS } \\
IPCC & Intergovernemental Panel for Climate Change \\
FDI & Forgien Direct Investment \\
CO2 & Carbon Dioxide \\
PHH & Pollution Haven Hypothesis \\
MNCs & Multinational Corporations \\
LDC's & Less Developed Countries \\
WHO & World Health Organization \\
PM & Particulate Matter \\
GHG & Greenhouse Gas Emissions \\
ASEAN & Association for South East Asian Nations \\
ECM & Error Correction Model \\
ARDL & Autoregressive Distributed Lag Model \\
SIC & Schwartz Information Criteria \\
FDIPGDP & Net inflow of investement as a percentage of GDP \\
GDPCAP & Per Capita GDP \\
TOPENESS & Trade Openness \\
CO2PCAP & Carbon Dioxide Emissions per Capita \\
Urban & Urbanization \\
CUSUM & Cumulative Sum Control Chart
\end{tabular}

\section{REFERENCES}

[1] F. Bilgili, E. Kocak, and U. Bulut, "The dynamic impact of renewable energy consumption on $\mathrm{CO} 2$ emissions: A revisited Environmental Kuznets Curve approach," Renewable and Sustainable Energy Reviews, vol. 54, pp. 838-845, Feb. 2016, https://doi.org/10.1016/j.rser. 2015.10.080.

[2] O. Hoegh - Guldberg et al., "Chapter 3: Impacts of $1.5^{\circ} \mathrm{C}$ global warming on natural and human systems," Intergovernmental Panel on Climate Change, 2018.

[3] Y. Liu, Y. Hao, and Y. Gao, "The environmental consequences of domestic and foreign investment: Evidence from China," Energy Policy, vol. 108, pp. 271-280, Sep. 2017, https://doi.org/10.1016/j.enpol. 2017.05.055.

[4] L.-S. Lau, C.-K. Choong, and Y.-K. Eng, "Carbon dioxide emission, institutional quality, and economic growth: Empirical evidence in 
Malaysia," Renewable Energy, vol. 68, pp. 276-281, Aug. 2014, https://doi.org/10.1016/j.renene.2014.02.013.

[5] G. Boluk and M. Mert, "The renewable energy, growth and environmental Kuznets curve in Turkey: An ARDL approach," Renewable and Sustainable Energy Reviews, vol. 52, pp. 587-595, Dec. 2015, https://doi.org/10.1016/j.rser.2015.07.138.

[6] A. Khan and Y.-H. Kim, "Foreign Direct Investment in Pakistan: Policy Issues and Operational Implications," Asian Development Bank, Philippines, Asia, 66, Jul. 1999. Accessed: Aug. 21, 2021. [Online]. Available: https://www.adb.org/publications/foreign-direct-investmentpakistan-policy-issues-and-operational-implications.

[7] M. Mert and A. E. Caglar, "Testing pollution haven and pollution halo hypotheses for Turkey: a new perspective," Environmental Science and Pollution Research, vol. 27, no. 26, pp. 32933-32943, Sep. 2020, https://doi.org/10.1007/s1 1356-020-09469-7.

[8] A. A. Mahessar, S. Qureshi, A. L. Qureshi, K. Ansari, and G. H. Dars, "Impact of the Effluents of Hyderabad City, Tando Muhammad Khan, and Matli on Phuleli Canal Water," Engineering, Technology \& Applied Science Research, vol. 10, no. 1, pp. 5281-5287, Feb. 2020, https://doi.org/10.48084/etasr.3269.

[9] A. A. Siyal, S. R. Samo, Z. A. Siyal, K. C. Mukwana, S. A. Jiskani, and A. Mengal, "Assessment of Air Pollution by PM10 and PM2.5 in Nawabshah City, Sindh, Pakistan," Engineering, Technology \& Applied Science Research, vol. 9, no. 1, pp. 3757-3761, Feb. 2019 , https://doi.org/10.48084/etasr.2440.

[10] M. Bouznit and M. del P. Pablo-Romero, "CO2 emission and economic growth in Algeria," Energy Policy, vol. 96, pp. 93-104, Sep. 2016, https://doi.org/10.1016/j.enpol.2016.05.036.

[11] Y.-J. Joo, C. S. Kim, and S.-H. Yoo, "Energy Consumption, Co2 Emission, and Economic Growth: Evidence from Chile," International Journal of Green Energy, vol. 12, no. 5, pp. 543-550, May 2015, https://doi.org/10.1080/15435075.2013.834822.

[12] F. M. Mirza and A. Kanwal, "Energy consumption, carbon emissions and economic growth in Pakistan: Dynamic causality analysis," Renewable and Sustainable Energy Reviews, vol. 72, pp. 1233-1240, May 2017, https://doi.org/10.1016/j.rser.2016.10.081.

[13] N. A. Neequaye and R. Oladi, "Environment, growth, and FDI revisited," International Review of Economics \& Finance, vol. 39, pp. 47-56, Sep. 2015, https://doi.org/10.1016/j.iref.2015.06.002.

[14] R. Kastratovic, "Impact of foreign direct investment on greenhouse gas emissions in agriculture of developing countries," Australian Journal of Agricultural and Resource Economics, vol. 63, no. 3, pp. 620-642, 2019, https://doi.org/10.1111/1467-8489.12309.

[15] M. B. Hitam and H. B. Borhan, "FDI, Growth and the Environment: Impact on Quality of Life in Malaysia," Procedia - Social and Behavioral Sciences, vol. 50, pp. 333-342, Jan. 2012, https://doi.org/ 10.1016/j.sbspro.2012.08.038.

[16] J. Hu, Z. Wang, Y. Lian, and Q. Huang, "Environmental Regulation, Foreign Direct Investment and Green Technological ProgressEvidence from Chinese Manufacturing Industries," International Journal of Environmental Research and Public Health, vol. 15, no. 2, Feb. 2018, Art. no. 221, https://doi.org/10.3390/ijerph15020221.

[17] Y. Xing and C. D. Kolstad, "Do Lax Environmental Regulations Attract Foreign Investment?," Environmental and Resource Economics, vol. 21, no. 1, pp. 1-22, Jan. 2002, https://doi.org/10.1023/A:1014537013353.

[18] D. Talukdar and C. M. Meisner, "Does the Private Sector Help or Hurt the Environment? Evidence from Carbon Dioxide Pollution in Developing Countries," World Development, vol. 29, no. 5, pp. 827-840, May 2001, https://doi.org/10.1016/S0305-750X(01)00008-0.

[19] Y. Merican, Z. Yusop, Z. Noor, and S. Law, "Foreign Direct Investment and the Pollution in Five ASEAN Nations," International Journal of Economics and Management, vol. 1, no. 2, pp. 245-261, Jun. 2007.

[20] C. G. Lee, "Foreign direct investment, pollution and economic growth: evidence from Malaysia," Applied Economics, vol. 41, no. 13, pp. 17091716, May 2009, https://doi.org/10.1080/00036840701564376.

[21] M. A. Cole, R. J. R. Elliott, and L. Zhang, "Foreign Direct Investment and the Environment," Annual Review of Environment and Resources, vol. 42, no. 1, pp. 465-487, 2017, https://doi.org/10.1146/annurevenviron-102016-060916.

[22] R. Hoffmann, C.-G. Lee, B. Ramasamy, and M. Yeung, "FDI and pollution: a granger causality test using panel data," Journal of International Development, vol. 17, no. 3, pp. 311-317, 2005, https://doi.org/10.1002/jid.1196.

[23] A. R. Ridzuan, A. H. M. Noor, and E. M. Ahmed, "The Impact of Foreign Direct Investment towards Carbon Dioxide Level: Pollution Havens Model for ASEAN5 Countries," Asian Journal of Agricultural Extension, Economics \& Sociology, pp. 392-404, Jun. 2014, https://doi.org/10.9734/AJAEES/2014/10411.

[24] M. T. Rock, "Pollution intensity of GDP and trade policy: Can the World Bank be wrong?," World Development, vol. 24, no. 3, pp. 471479, Mar. 1996, https://doi.org/10.1016/0305-750X(95)00152-3.

[25] X. Yao, R. Yasmeen, Y. Li, M. Hafeez, and I. U. H. Padda, "Free Trade Agreements and Environment for Sustainable Development: A Gravity Model Analysis," Sustainability, vol. 11, no. 3, Jan. 2019, Art. no. 597, https://doi.org/10.3390/su11030597.

[26] H. Zhang, "CO2 Emission Embodied in International Trade: Evidence for China," International Journal of Economics and Finance, vol. 7, no. 2, pp. 138-143, Jan. 2015, https://doi.org/10.5539/ijef.v7n2p138.

[27] Danish, M. A. Baloch, and S. Suad, "Modeling the impact of transport energy consumption on $\mathrm{CO} 2$ emission in Pakistan: Evidence from ARDL approach," Environmental Science and Pollution Research, vol. 25, no. 10, pp. 9461-9473, Apr. 2018, https://doi.org/10.1007/s11356018-1230-0.

[28] B. Talbi, "CO2 emissions reduction in road transport sector in Tunisia," Renewable and Sustainable Energy Reviews, vol. 69, pp. 232-238, Mar. 2017, https://doi.org/10.1016/j.rser.2016.11.208.

[29] "Pakistan | Data," The World Bank. https://data.worldbank.org/country/ pakistan?view=chart (accessed Aug. 21, 2021).

[30] H. Pesaran and Y. Shin, "An Autoregressive Distributed Lag Modeling Approach to Co-integration Analysis," Econometncs and Economic Theory in the 20st Century: The Ragnar Frisch Centennial Symposium, vol. 31, Feb. 1995, https://doi.org/10.1017/CCOL0521633230.011.

[31] M. H. Pesaran, Y. Shin, and R. J. Smith, "Bounds testing approaches to the analysis of level relationships," Journal of Applied Econometrics, vol. 16, no. 3, pp. 289-326, 2001, https://doi.org/10.1002/jae.616.

[32] H. Mahmood, "FDI, Population Density and Carbon Dioxide Emissions: A Case Study of Pakistan," Iranica Journal of Energy \& Environment, vol. 3, no. 4, pp. 354-360, Jan. 2012, https://doi.org/10.5829/ idosi.ijee.2012.03.04.09.

[33] R. Ali, K. Bakhsh, and M. A. Yasin, "Impact of urbanization on CO2 emissions in emerging economy: Evidence from Pakistan," Sustainable Cities and Society, vol. 48, Jul. 2019, Art. no. 101553, https://doi.org/ 10.1016/j.scs.2019.101553.

[34] P. Sadorsky, "The effect of urbanization on CO2 emissions in emerging economies," Energy Economics, vol. 41, pp. 147-153, Jan. 2014 https://doi.org/10.1016/j.eneco.2013.11.007.

[35] K. Hamid, "Is Foreign Direct Investment a Cause of Environmental Degradation in Pakistan? An ARDL Approach to Cointegration," Journal of Management and Research, vol. 3, no. 2, pp. 60-76, Dec. 2016, https://doi.org/10.29145/jmr/32/0302003. 